\title{
MINIREVIEW
}

\section{Chicken anemia virus: A deadly pathogen of poultry}

\author{
A. J. FATOBA, M. A. ADELEKE
}

\begin{abstract}
Discipline of Genetics, School of Life Sciences, College of Agriculture, Engineering and Science, University of KwaZulu-Natal,
\end{abstract} Westville, P/Bag X54001, Durban, 4000, South Africa

Received January 18, 2018; revised July 16, 2018; accepted February 4, 2019

\begin{abstract}
Summary. - Chicken infectious anemia (CIA) is an immunosuppressive disease that causes great economic loss in poultry industry globally. This disease is caused by chicken anemia virus (CAV), an icosahedral and single-stranded DNA virus that is transmitted both vertically and horizontally. CAV, which belongs to the genus Gyrovirus has been reported in human, mouse and dog feces. Rapid identification of different strains of gyrovirus with high similarity to CAV has heightened public concern on this virus. Clinical symptoms of this disease such as intramuscular hemorrhage, weight loss, anemia and bone marrow aplasia are prominent in young chickens, while adult chickens experience subclinical symptoms. Biosecurity measures such as good management practice and vaccination have been the most reliable control strategy against this virus. Therefore, this study reviews the current state of CAV under the following subheadings (i) Chicken anemia virus (ii) Pathogenesis of CAV (iii) Serological evaluation of host antibodies to CAV (iv) Association of Marek's disease and infectious bursa disease with CAV infection (v) Genetic diversity and phylogenetics of CAV strains (vi) Current and future vaccine strategy in the control of CAV. In conclusion, improvement on DNA and recombinant vaccines strategy could curtail the economic impact of CAV on poultry birds.
\end{abstract}

Keywords: adjuvant; CAV; chicken; disease

\section{Contents:}

1. Introduction

2. Chicken anemia virus $(\mathrm{CAV})$

3. Pathogenesis of CAV

4. Serological evaluation of host antibodies to CAV

5. Association of Marek's disease and infectious bursa disease with CAV infection

6. Genetic diversity and phylogenetics of CAV strains

7. Current and future vaccine strategy in the control of CAV

8. Conclusion

*Corresponding author. E-mail: adelekem@ukzn.ac.za; phone: +27-0-633832746.

Abbreviations: $\mathrm{CAV}=$ chicken anemia virus; $\mathrm{CIA}=$ chicken infectious anemia; IFAT $=$ indirect fluorescent antibody test; IFN = interferon; IL = interleukin; SPF = specific pathogen free; $\mathrm{VNT}=$ virus neutralizing test; $\mathrm{VP}=$ viral protein

\section{Introduction}

Over decades, chickens, among many avian species, have drawn the attention of researchers. Agricultural purposes of chickens in supplying meats and eggs could be one of major factors for this attention. Despite the economic, social and food security benefits of chickens, disease outbreaks remain the major challenge to poultry industry globally. Chickens are reservoir of many infectious pathogens, which could be transmitted to humans through contaminated eggs and meat (Hald, 2010) and hence, there is a need for their protection.

Chicken infectious anemia (CIA) is a disease that affects poultry industry globally (Schat, 2009). It is caused by chicken anemia virus (CAV), which is a non-enveloped, icosahedral, single-stranded DNA virus belonging to the genus Gyrovirus of the family Anelloviridae (Rosario et al., 2017). The prime targets of this virus are the hemocytoblast of the bone marrow and precursor lymphocytes of the 
thymus (Noteborn, 2004). The immunosuppressive ability of CAV associated with depletion of lymphocyte has given this virus a wide recognition in the poultry industry (Van Santen et al., 2004). Vertical and horizontal transmissions are common in young and adult chickens, respectively (Miller and Schat, 2004). The severe damages caused by this virus such as weight loss, anemia, intramuscular hemorrhage, lymphoid atrophy and bone marrow aplasia are mostly seen among the young chickens less than 2 weeks of age and void of maternally-derived antibodies (Miller and Schat, 2004).

However, adult chickens are also infected horizontally with this virus, though with subclinical symptoms after the maternal antibodies wane (Trinh et al., 2015). This causes poor growth and exposes them to secondary pathogens, thereby contributing to major economic loss (Hoerr, 2010).

Identification of different strains of gyrovirus in humans, dog, mouse and other birds (Rijsewijk et al., 2011; Chu et al., 2012; Zhang et al., 2014; Fang et al., 2017; Li et al., 2017) with high similarity with CAV has heightened the public concern of this virus, which has generated different strategies in its control.

This study reviews the current state of CAV in poultry by discussing the chicken anemia virus, pathogenesis of CAV, serological evaluation of host's antibodies to CAV, association of Marek's disease and infectious bursa disease with CAV infection, genetic diversity and phylogenetics of CAV strains and current vaccine strategy in the control of CAV. In addition, recommendation on vaccine strategy that could be of help in the control of this virus is also highlighted.

\section{Chicken anemia virus (CAV)}

Chicken anemia virus is one of the deadly diseases of poultry worldwide as it affects the immune status of birds, which is detrimental to their productivity (Schat, 2009). It is a non-enveloped, icosahedral single-stranded DNA virus belonging to the genus Gyrovirus of the family Anelloviridae (Rosario et al., 2017). Till date, poultry has been the only natural host of this virus but of recent, a human variant of this virus has been discovered with similar pathogenic qualities as that of avian gyrovirus (Phan et al., 2015). The disease caused by this virus is mostly known as chicken infectious anemia. The virus has an open reading frame coding for three proteins called Viral protein 1 (VP1), Viral protein 2 (VP2) and Viral protein 3 (VP3) (Lacorte et al., 2007). Both viral proteins 1 and 2 are prime targets in vaccine design to induce neutralizing antibodies in the host, mainly chickens (Moeini et al., 2011). Viral protein 3 is regarded as Apoptin, as it facilitates apoptosis in the transformed cells, making it a potential agent in the control of cancer disease (Ganar et al., 2017). CAV affects both male and female chickens of all ages, thereby contributing to the severe damage it causes in the poultry industry (Umar et al., 2014). It is most common in broilers as compared to other chicken types (Umar et al., 2014). Like other viral infectious diseases such as Marek's disease and infectious bursa disease, which suppress the host immune system of their host, CAV is a well-known immunosuppressive virus that exposes its host to several secondary infections that collectively weaken the immune system (Zhang et al., 2015).

\section{Pathogenesis of CAV}

Chicken aneamia virus can be transmitted both vertically and horizontally (Miller and Schat, 2004; Smyth and Schat, 2013). Vertical transmission entails the transfer from breeders to their progeny, while horizontal transfer involves transmission via feathers, oral contamination and feces (Davidson et al., 2008). The virus attacks young chickens that are void of the maternal antibodies within the first two weeks of age and cause severe damage to tissues and organs (Miller and Schat, 2004). Among the chicks that have maternally inherited antibodies, vertical transmission of the virus is not possible but horizontal transmission with subclinical symptoms is possible as the antibodies wane (Davidson et al., 2008). This causes poor growth and makes chickens susceptible to some secondary infection such as Marek's disease, infectious bursa disease and other adenoviral infections (Senthilkumar et al., 2006). Some of the severe damages of this virus include lymphoid atrophy, weight loss, aplasia of bone marrow, muscular depletion of RBC and anemia (Dhama et al., 2008). The prime targets of this virus are hemocytoblast and lymphocyte precursor cells. The hematopoietic cells in the bone marrow become damaged, thereby reducing drastically the number of erythrocyte and myeloid cells, which contributes to the level of anemia in the host (Van Santen et al., 2004). The hematopoietic cells also produce thrombocytes associated with blood clothing, and therefore their damage by CAV is associated with intramuscular hemorrhage in the host (Kuscu and Gurel, 2008). The $\mathrm{T}$ lymphocytes are also a major target of CAV with effect on the downstream adaptive immunity (Adair, 2000). The B cells are not susceptible to CAV directly but indirect impact on B cells has been associated with damage to cytokines and other molecules (Adair, 2000). Different studies have shown the reduction of cytokines such as interleukin 2 (IL-2) with downstream effect on macrophages, neutrophils and the phagocytic activities of the immune system, which is the main cause of the immunosuppressive action of CAV (Natesan et al., 2006; Oluwayelu et al., 2010). In addition to the suppression of the immune molecules, interferon gamma $($ IFN- $\gamma$ ) has been reported to increase in first few days of infection, followed by gradual reduction (Natesan et al., 2006). Recent study by Wani et al. (2016) evaluated the impact of 
viral load of CAV on immunocytological and histopathological parameters. The studies confirmed the highest viral load in blood, thymus and spleen at 15 days post infection with minimal expression in liver, bone marrow and bursa. Drastic reduction of cytokines (IL-2, IL-1, IL-12) at all doses with a 3-15-fold initial increase of IFN- $\gamma$ at the early stage of infection was also established. The reduction of CD4+ and $\mathrm{CD} 8+$ in CAV infected chicks has also been reported (Adair, 2000; Kuscu and Gurel, 2008; Wani et al., 2016).

\section{Serological evaluation of host antibodies to CAV}

CAV affects chickens of all types throughout the world. To prevent the vertical transmission of this virus from breeders to their progenies, vaccination of the breeders becomes necessary, as it ensures seroconversion by the production and transfer of maternal antibodies that protect the progeny from the infection (Umar et al., 2014). Evaluation of these antibodies can be assessed in the breeders through different methods to ascertain the safety of new chicks.

Enzyme linked immunosorbent assay (ELISA), indirect fluorescent antibody test (IFAT) and virus neutralizing test (VNT) have been used in different studies to detect neutralizing antibodies during CIA (Wani et al., 2014; Zhang et al., 2015). VNT is regarded as the best techniques for chicken infectious anemia virus due to its sensitivity. However, the drawback in the use of this techniques is that it is time consuming and laborious. Due to unsuitability of both VNT and IFAT for large number of samples, ELISA method has been embraced by many researchers for the studies of antibodies against various pathogens (Sawant et al., 2015; Shen et al., 2015; Bissa et al., 2016).

The report of Hadimli et al. (2008) on the serological analysis of 922 sera samples collected from 32 flocks of Turkish chickens showed that 609 (66\%) were positive for antibodies to CAV by ELISA method. Similarly, $85.7 \%$ of 21 commercial layers flocks tested positive to anti-chicken infectious anemia virus antibodies using ELISA methods (Kuyucuoglu et al., 2003). Antibodies against CAV using ELISA kits have been reported among various chicken breeds in different countries: $84.72 \%$ in Egypt (Hegazy et al., 2014), $86 \%$ in Nigeria (Owoade et al., 2004), 67.3\% in Sudan (Ballal et al., 2005), 96.15\% in Malaysia (Hailemariam et al., 2008).

Recently, Ogawa et al. (2015) reported the use of blocking latex agglutination test (b-LAT) as an alternative antibodymeasurement technique for chicken infectious anemia virus. The technique involves the binding of monoclonal antibody to CAV antigen, which triggers specific antibodies. The reliability of the technique was confirmed by comparing it with other well-recognized techniques (VNT and IFAT) with total antibody incidence to CAV stated as follows: VNT (78.7\%), b-LAT (72.3\%) and IFAT (55.3\%). VNT and b-LAT showed significant sensitivity as compared to IFAT, while the user friendly and high speed associated with b-LAT gives this technique an edge over VNT and IFAT.

\section{Association of Marek's disease and infectious bursa disease with CAV infection}

Infectious bursa disease (IBD) is an acute and highly contagious disease among poultry chicks. The deteriorating effect of this virus is associated with high mortality among poultry chickens. IBD virus is a double-stranded RNA of the genus Avibirnavirus and the family Birnaviridae (Rosenberger et al., 2008). Horizontal transmission of the disease occurs through direct oral contact with infected chickens (Dolz and Majo, 2013). Some of the clinical signs of the disease include: anorexia, ruffled feathers and diarrhea (Dolz and Majo, 2013).

Marek's disease is an immune-suppressive disease that ravages young chickens (Witter, 2001). Due to the immunosuppression of this disease, the chicks are exposed to secondary infection (Schat, 2003). This disease affects egg production in layers and thus contributes to economic loss. The infection stages of Marek's disease include the cytolytic stage, latent stage, proliferation and transformation phase. The transformation phase is characterized by oncogenic transformation of CD4+ T cell leading to the formation of visceral tumors and lymphomas (Jarosinski et al., 2006; Boodhoo et al., 2016). The Marek's virus belongs to the herpesviruses, with three serotypes as of date: Gallid herpesvirus 2 (GaHV-2), Gallid herpesvirus 3 (GaHV-3) and Meleagrid herpesvirus 1 (MeHV-1) (Davison et al., 2009). These serotypes differ in their biological and genomic similarities with GaHV-2 known for its oncogenic ability (Morimura et al., 1998).

The co-expression of MD and CAV has been reported to cause serious health damage to the growth of different chickens (Davidson et al., 2013). CAV has been isolated among chicken breeds infected with Marek's disease in different countries of the world (Fehler and Winter, 2001; Zanella et al., 2001; Davidson et al., 2004).

Haridy et al. (2009) reported the co-infection of CAV at 4 weeks with chickens infected with Marek's disease at 1 day old. The study confirmed the high mortality rate of $64.3 \%$ and mean death rate of 30 days of very virulent $\mathrm{MD}-\mathrm{CAV}-$ infected chicks as compared to mortality rate of $52.6 \%$ and mean death rate of 32 days of the virulent MD-infected chicks. Histopathological changes of the bone marrow at 4 weeks of virulent MD-CAV-infected chicks were associated with the high cytotoxicity of CAV on bone marrow hematopoietic precursor cells. The co-infection of MD and CAV has a great damage on the T-lymphocyte (Schat, 2004). Of the 37 spleens and 12 livers confirmed to be infected with 
MD, CAV was found in the lymphoma of 9 spleens and 2 livers, respectively (Ahmed et al., 2016).

Further immunohistochemical analysis confirmed the presence of CAV antisera in MD-infected chickens at 4 weeks old. Similar report of the presence of CAV antisera in 4-week-old MD- infected chickens has been established (Haridy et al., 2012). CAV infection has been associated with poor vaccine-induced protection against Marek's disease (Markowski-Grimsrud and Schat, 2003). In contrast, Sun et al. (2017) recently compared the vaccine protection of CVI 998/814 against the MDV isolate BS/15 and Md5 in specific pathogen free chicken (SPF-chicken) of white leghorn chickens in China. The unvaccinated SPF chickens showed MD mortality of $85.7 \%$ and $80 \%$ from both BS/15 and Md5 isolates, respectively. However, among the vaccinated SPF chickens, the vaccines CVI 998 and 814 provided protective index of 33.3 and 66.7 to SPF chicken against BS/15, while the protective index of vaccine CVI 998 and 814 against Md5 was $92.9 \%$ and $100 \%$, respectively. The study confirmed that poor vaccination protection against MD could be due to different strains of MDV. Due to synergy between these viruses in expressing both clinical and subclinical signs in chicken, detection of these viruses becomes important. Different studies have used quantitative PCR for the detection of each of the viruses (Van Santen et al., 2004; Islam et al., 2006; Cortes et al., 2011). Moreover, multiplex qPCR has also been used to detect viruses in infected chickens (Davidson et al., 2013).

Similarly, CAV has also been reported to work synergistically with infectious bursa disease virus (IBDV) to suppress the immune system of birds (Miles et al., 2001; Toro et al., 2009; Hoerr, 2010). Sometimes it is difficult to separate the clinical signs of IBD from CIA, leading to misdiagnosis among poultry clinicians (Smyth and Schat, 2013; Haridy et al., 2012).

Co-infection with both CAV and infectious bursa disease virus (IBDV) has shown that very virulent IBD virus (vvIBDV) inhibits the production of neutralizing antibodies against CIA in chickens (Kuscu and Gurel, 2008). The increase of prevalence of CAV and IBDV in chicken premises is due to the resistance of these viruses to both physical and chemical agents (Toro et al., 2009). Schat and Van Santen (2008) reported that the hemorrhage seen in IBD-infected chickens may be due to CAV and not IBDV. The co-infection of IBDV and CAV has been reported in different countries (Toro et al., 2009; Adedeji et al., 2016).

\section{Genetic diversity and phylogenetics of CAV strains}

Among the viral protein genes present in the CAV genome, VP1 is known to be less conserved. The variability of VP1 gene among CAV isolates has been reported and it has influenced diversity of different CAV isolates (Schat, 2003; Eltahir et al., 2011; Kye et al., 2013).

Molecular characterization of CAV genome reveals a hypervariable region (position 139 to 151) of VP1 protein, of which position 139 and 144 are known to play key role in the growth and spread of the virus (Renshaw et al., 1996). In addition, viral infection has been reported to be pathogenic if the amino acid at the position 394 of the VP1 protein is glutamine (Yamagushi et al., 2001). The presence of glutamine has been consistent in this position among different CAV strains (Eltahir et al., 2011; Kye et al., 2013; Li et al., 2017).

Moreover, the recent study by Li et al. (2017) reported the presence of the amino-acid Isoleucine (Ile) at position 75 and 125 of the VP1 protein among chicken and mouse CAV strains isolated from different provinces in China. This is in contrast to the amino acids valine (Val) and leucine (Leu) known for these positions in CAV. Similarly, Eltahir et al. (2011) reported 8 nucleotide mutations in VP3 protein, which are specific to CAV strain of Chinese origin couple with 10 and 60 mutations in VP2 and VP1, respectively. The diversity of CAVs VP1 proteins has been reported among CAV strains in different countries (Oluwayelu et al., 2008; Nayabian and Mardani, 2013; Zhang et al., 2013). Based on the diversity of CAV viral proteins, different clades of CAV strains have been reported with no consistent classification among CAV strains of different origins (Simionatto et al., 2006; Eltahir et al., 2011b; Zhang et al., 2013). Although previous classification was criticized based on low bootstrap and non-existence of monophyletic group, recent study by Li et al. (2017) on 24 novel CAV sequences, supported by topology and high posterior probability $(>0.89)$, classified CAV into 8 major lineages, which are scattered across different branches with no clear distribution. The author rooted the discrepancy of CAV phylogeny to the complexity of CAV on genome, pathology and epidemiology level, which require further study. To further confirm the diversification of CAV strain in different geographical region using 1000 bootstrap replicates, Olszewska-Tomczyk et al. (2016) classified Polish CAV strains into 2 main clades based on the nucleotide sequences of the VP1 protein. Different studies on the diversity of CAV isolates in different countries have been reported (Ducatez et al., 2008; Kim et al., 2010; Snoeck et al., 2012). The rapid identification of novel CAV strains in different parts of the world is of no doubt the result of the resistance of the virus to different vaccines. Therefore, there is need for a new approach in vaccine design.

\section{Current and future perspective in the control of CAV}

Vaccination as shown in Fig. 1, combined with good poultry management, has been the only available control measure for preventing the vertical transmission of CAV 


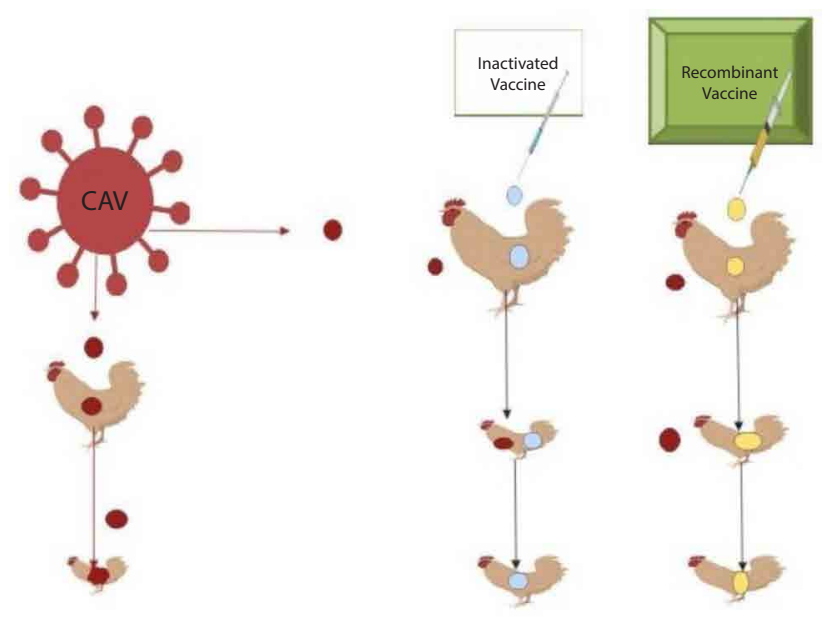

Fig. 1

Schematic diagram showing different vaccine strategies against CAV

from breeder hens to their progenies. Progenies of vaccinated breeders derive maternal antibodies, which protect them from severe clinical signs of chicken infectious anemia (Todd, 2000). Despite the availability of maternally derived antibodies, which wane after three weeks of age, chickens are still susceptible to this infection though with subclinical symptoms (Hoerr, 2010). Several traditional vaccines have proven to be effective against this virus, but their limitation has led to the emergence of myriads of modern vaccines with potential protection ability, though many are still on clinical considerations. The current live attenuated vaccine provides protection against CAV and triggers high immune response, but the constraint of such vaccine is the ability of the virus to revert to its virulent nature and the risk of horizontal transmission of the virus to chickens (Sawant et al., 2015).

Inactivated vaccine has been regarded as safe because it is stable, though with low immune response, which could be addressed with appropriate vaccine adjuvants. As against the shift in tide from traditional vaccine to recombinant and DNA vaccines, Zhang et al. (2015) recently reported the efficacy of inactivated strain (GD-G-12) of CAV as reliable vaccine against CIA. The isolate, which was described as highly pathogenic, was inactivated by $\beta$-propiolactone hydrolysis in contrast to the conventional formaldehyde method. Vaccinated hen showed $98-100 \%$ protection when challenged with CAV strain GD-G-12 compared with the unvaccinated, which showed $100 \%$ mortality rate. In addition, the level of antibodies expression evaluated by ELISA method was at peak in the vaccinated breeder hens and chicks, an indication of maternal transmission. Inability of CAV strain to grow to high titer levels in embryo or cell culture coupled with potential reversion to virulence are some of the drawbacks of the current vaccines (live and killed) against chicken infectious anemia (Sawant et al., 2015; Shen et al., 2015). Therefore, the need for DNA and recombinant vaccines becomes imperative for the control of CAV.

Studies on chicken anemia viral protein 1 and 2 (VP1 and VP2) have been reported to induce neutralizing antibodies against CAV (Lacorte et al., 2007; Trinh et al., 2015). The combination of these viral protein genes was cloned into DNA vaccines named as pBudVP1 and pBudVP2-VP1, respectively. SPF chickens vaccinated with (pBudVP2-VP1) at 4 weeks showed antibodies titer value of 1853 compared to the other grouped vaccinated with (pBudVP1) with no antibody (Moeini et al., 2011). Similarly, recombinant form of viral protein 1(rVP1) and pigeon interferon gamma (rPiIFN- $\gamma$ ) was recently combined as subunit vaccine against chicken anemia virus (Shen et al., 2015). The chickens vaccinated with $(\mathrm{rVP} 1+\mathrm{rPiIFN}-\gamma)$ showed higher antibodies titer value as compared with the group with only inactivated vaccine and recombinant viral protein (rVP1) group. Th-1 type cytokine was higher in the combined recombinant vaccine than in the inactivated group and rVP1 group. Antibody induction by vaccine has been reported as an effective means of evaluating subunit protein efficacy against CAV (Sawant et al., 2015; Trinh et al., 2015).

Despite the recent development in the recombinant and DNA vaccines for CAV, the virus is still much prevalent. Therefore, future vaccine design should consider improving the induction of the neutralizing antibodies against CAV by combining both recombinant and DNA vaccine in a prime boost regimen with a suitable adjuvant. This could curtail the poor immunogenicity of both recombinant and DNA vaccines.

\section{Conclusion}

Chicken infectious anemia is an immunosuppressive infectious disease, which is caused by chicken anemia virus. The virus is transmitted both vertically and horizontally. The immunosuppressive quality of this virus has given it a wide recognition in the poultry industry. The economic impact of CAV on poultry birds is alarming and this has generated strict adherence to biosecurity measures such as vaccination and good poultry management among farmers. With the upsurge of novel CAV strains reported in different geographical locations, it is unlikely that most current vaccines would be effective against this virus. This, therefore, demands a new approach in vaccine design, taking these novel strains into consideration. Recent advances in DNA and recombinant vaccines have shown promising effect in the control of CAV. Although, the poor immunogenicity of both DNA and recombinant vaccines is still a limiting factor, future studies could explore the combination of these vac- 
cines either as a prime-boost or prime-boost with suitable adjuvant to increase the levels of neutralizing antibodies against this virus.

Acknowledgment. The authors wish to thank the College of Agriculture, Engineering and Science, University of KwaZulu-Natal South Africa for providing tuition fee remission for doctoral study of the first author.

\section{References}

Adair BM, Dev. Comp. Immunol. 24, 247-255, 2000. https://doi. org/10.1016/S0145-305X(99)00076-2

Adedeji AJ, Sati NM, Pewan SB, Ogbu KI, Adole JA, Lazarus DD, Ijiwo SJ, Okpanachi A, Nwagbo IO, Joannis TM, Abdu PA, Vet. Sci. Res. Rev. 2, 60-65, 2016.

Ahmed MS, Ono H, Sasaki J, Ochiai K, Goryo M, J. Vet. Med. Sci. 78, 825-829, 2016. https://doi.org/10.1292/jvms.15-0615

Ballal A, Elhussein AM, Abdelrahim IS, J. Anim. Vet. Adv. 4, 666-667, 2005.

Bissa M, Quaglino E, Zanotto C, Illiano E, Rolih V, Pacchioni S, Cavallo F, Morghen CD, Radaelli A, Antiviral Res. 134, 182-191, 2016. https://doi.org/10.1016/j.antiviral.2016.09.002

Boodhoo N, Gurung A, Sharif S, Behboudi S, Vet. Res. 47, 119, 2016. https://doi.org/10.1186/s13567-016-0404-3

Chu DK, Poon LL, Chiu SS, Chan KH, Ng EM, Bauer I, Cheung TK, Ng IH, Guan Y, Wang D, Peiris JM, J. Clin. Virol. 55, 209-213, 2012. https://doi.org/10.1016/j.jcv.2012.07.001

Cortes AL, Montiel ER, Lemiere S, Gimeno IM, Avian Dis. 55, 302-310, 2011. https://doi.org/10.1637/9578-101510ResNote. 1

Davison AJ, Eberle R, Ehlers B, Hayward GS, McGeoch DJ, Minson AC, Pellett PE, Roizman B, Studdert MJ, Thiry E, Arch. Virol. 154, 171-177, 2009. https://doi.org/10.1007/ s00705-008-0278-4

Davidson I, Artzi N, Shkoda I, Lublin A, Loeb E, Schat KA, Virus Res. 132, 152-159, 2008. https://doi.org/10.1016/j.virusres.2007.11.012

Davidson I, Kedem M, Borochovitz H, Kass N, Ayali G, Hamzani E, Perelman B, Smith B, Perk S, Avian Dis. 48, 108-118, 2004. https://doi.org/10.1637/7072

Davidson I, Raibshtein I, Al-Touri A, Avian Dis. 57, 532-538, 2013. https://doi.org/10.1637/10418-101012-Reg.1

Dhama K, Mahendran M, Gupta PK, Rai A, Vet. Res. Commun. 32, 341-356, 2008. https://doi.org/10.1007/s11259-0089040-3

Dolz R, Majo N, In Gimeno IM (Ed.), Grupo Asis Biomedia, Zazagoza 2013, pp. 67-87, 2013.

Ducatez MF, Chen H, Guan Y, Muller CP, Avian Dis. 52, 68-73, 2008. https://doi.org/10.1637/8049-070407-Reg

Eltahir YM, Qian K, Jin W, Wang P, Qin A, Virol. J. 8, 145, 2011 a. https://doi.org/10.1186/1743-422X-8-145

Eltahir YM, Qian K, Jin W, Qin A, Virol. J. 8, 512, 2011b. https:// doi.org/10.1186/1743-422X-8-512
Fang L, Li Y, Wang Y, Fu J, Cui S, Li X, Chang S, Zhao P, BioMed Res. Int. Vol. 2017, Article ID 6707868, 2017.

Fehler F, Winter C, International Symposium on Infectious Bursal Disease and Chicken Infectious Anemia. Rauischolzhausen, pp. 391-394, 2001.

Ganar K, Shah M, Kamdi BP, Kurkure NV, Kumar S, Microb. Pathog. 102, 113-119. 2017. https://doi.org/10.1016/j. micpath.2016.11.017

Hadimli HH, Erganiş O, Gueler L, Uçan US, Turk. J. Vet. Anim. Sci. 32, 79-84, 2008.

Hailemariam Z, Omar AR, Hair-Bejo M, Giap TC, Virol. J. 5, 128, 2008. https://doi.org/10.1186/1743-422X-5-128

Hald T, Analysis of the baseline survey on the prevalence of Campylobacter in broiler batches and of Campylobacter and Salmonella on broiler carcasses in the EU, 2008, Part A: Campylobacter and Salmonella prevalence estimates. European Food Safety Authority, 2010.

Haridy M, Goryo M, Sasaki J, Okada K, Avian Pathol. 38, 469-483, 2009. https://doi.org/10.1080/03079450903349162

Haridy M, Sasaki J, Okada K, Goryo M, Res. Vet. Sci. 93, 1353-1360, 2012. https://doi.org/10.1016/j.rvsc.2012.05.004

Hegazy A, Abdallah F, Abd-el Samie IK, Nazim A, Assiut Vet. Med. J. 60, 142, 2014.

Hoerr FJ, Avian Dis. 54, 215, 2010. https://doi.org/10.1637/8909043009-Review.1

Islam A, Cheetham BF, Mahony TJ, Young PL, Walkden-Brown SW, J. Virol. Methods 132, 127-134, 2006. https://doi. org/10.1016/j.jviromet.2005.10.009

Jarosinski KW, Tischer BK, Trapp S, Osterrieder N, Expert Rev. Vaccines 5, 761-772, 2006. https://doi. org/10.1586/14760584.5.6.761

Kim HR, Kwon YK, Bae YC, Oem JK, Lee OS, Poult. Sci. 89, 2426-2431, 2010. https://doi.org/10.3382/ps.2010-00911

Kuscu B, Gürel A, J. Vet. Sci. 9, 15-23, 2008. https://doi.org/10.4142/ jvs.2008.9.1.15

Kuyucuoglu Y, Hadimli HH, Kenar B, Ucan US, Vet. Hek. Mikrobiyol. Derg. 3, 21-26, 2003.

Kye SJ, Kim JY, Seul HJ, Kim S, Kim SE, Lee HS, Sorn S, Choi KS, Poult. Sci. 92(10), 2681-2686, 2013. https://doi. org/10.3382/ps.2013-03204

Lacorte C, Lohuis H, Goldbach R, Prins M, Virus Res. 129, 80-86, 2007. https://doi.org/10.1016/j.virusres.2007.06.020

Li Y, Fang L, Cui S, Fu J, Li X, Zhang H, Cui Z, Chang S, Shi W, Zhao P, Front. Microbiol. 8, 2017.

Markowski-Grimsrud CJ, Schat KA, Immunology 109, 283-294, 2003. https://doi.org/10.1046/j.1365-2567.2003.01643.x

Miles AM, Reddy SM, Morgan RW, Avian Dis. 1, 9-18, 2001. https:// doi.org/10.2307/1593006

Miller MM, Schat KA, Avian Dis. 48, 734-745, 2004. https://doi. org/10.1637/7271-090304R

Moeini H, Omar AR, Rahim RA, Yusoff K, Virol. J. 8, 119, 2011. https://doi.org/10.1186/1743-422X-8-119

Morimura T, Ohashi K, Sugimoto C, Onuma M, J. Vet. Med. Sci. 60, 1-8, 1998. https://doi.org/10.1292/jvms.60.1

Natesan S, Kataria JM, Dhama K, Rahul S, Baradhwaj N, Virus Res. 118, 78-86, 2006. https://doi.org/10.1016/j.virusres.2005.11.017 
Nayabian H, Mardani K, Avian Pathol. 42, 108-113, 2013. https:// doi.org/10.1080/03079457.2013.766668

Noteborn MH, Vet. Microbiol. 98, 89-94, 2004. https://doi. org/10.1016/j.vetmic.2003.10.003

Ogawa H, Bui VN, Nguyen TT, Gronsang D, Baatartsogt T, Kizito MK, AboElkhair M, Yamaguchi S, Nguyen VK, Imai K, J. Virol. Methods 221, 74-80, 2015.

Olszewska-Tomczyk M, Świętoń E, Minta Z, Śmietanka K, Avian Dis. 60, 70-74, 2016. https://doi.org/10.1637/11277091415-ResNote.1

Oluwayelu DO, Todd D, Olaleye OD, J. Vet. Res. 75, 353-357, 2008. Oluwayelu DO, Olaleye OD, Todd D, Afr. J. Med. Med. Sci. 39, 21-26, 2010.

Oluwayelu DO, Todd D, Ball NW, Scott AN, Oladele OA, Emikpe BO, Fagbohun OA, Owoade AA, Olaleye OD, Avian Dis. 49, 446-450, 2005. https://doi.org/10.1637/7339020705R.1

Owoade AA, Oluwayelu DO, Fagbohun OA, Ammerlaan W, Mulders MN, Muller CP, Avian Dis. 48, 202-205, 2004. https://doi.org/10.1637/7075

Phan TG, Da Costa AC, Zhang W, Pothier P, Ambert-Balay K, Deng X, Delwart E, Virus Genes 51, 132-135, 2015. https://doi. org/10.1007/s11262-015-1210-0

Renshaw RW, Soiné C, Weinkle T, O'Connell PH, Ohashi K, Watson S, Lucio B, Harrington S, Schat KA, J. Virol. 70, 8872-8878, 1996.

Rijsewijk FA, dos Santos HF, Teixeira TF, Cibulski SP, Varela AP, Dezen D, Franco AC, Roehe PM, Arch. Virol. 156, 10971100, 2011. https://doi.org/10.1007/s00705-011-0971-6

Rosario K, Breitbart M, Harrach B, Segalés J, Delwart E, Biagini P, Varsani A, Arch. Virol. 162, 1447-1463, 2017. https:// doi.org/10.1007/s00705-017-3247-y

Rosenberger JK, Saif MY, Jackwood DJ (2008): Chicken anemia virus. In: A laboratory manual for the isolation and identification of avian pathogens (Eds. Zavala LD, Swayne DE, Glisson JR, Pearson JE, Reed WM, Jackwood MW, Woolcock PR) 5th ed. American Association of Avian Pathologist, Jackonville, FL, pp. 188-194.

Santen VL, Joiner KS, Murray C, Petrenko N, Hoerr FJ, Toro H, Avian Dis. 48, 494-504, 2004. https://doi.org/10.1637/7155010904R

Sawant PM, Dhama K, Rawool DB, Wani MY, Tiwari R, Singh SD, Singh RK, Vaccine 33, 333-340, 2015. https://doi. org/10.1016/j.vaccine.2014.11.020

Schat KA, In Saif YM, Barnes HJ, Glisson JR, Fadly AM, Mcdougald LR, Swayne DE (Eds.), Diseases of Poultry. Ames: Iowa State University Press, pp. 182-202, 2003.

Schat KA, In Davison F, Nair V (Eds.), Marek's Disease: An Evolving Problem. 1st ed London: Elsevier Academic Press pp. 49-61, 2004.

Schat KA, Curr. Top. Microbiol. Immunol. 331, 151-183, 2009. https://doi.org/10.1007/978-3-540-70972-5 10

Schat KA, Van Santen VL, In Saif YM, Fadly AM, Glissen JR, Mcdougald LR, Nolan LK, Swayne D (Eds.), Diseases of Poultry. 12th Ed., pp. 211-235, 2008.
Senthilkumar N, Kataria JM, Dhama K, Rahul S, Baradhwaj N, Virus Res. 118, 78-86, 2006. https://doi.org/10.1016/j. virusres.2005.11.017

Shah MA, Song X, Xu L, Yan R, Li X, Res. Vet. Sci. 90, 72-77, 2011. https://doi.org/10.1016/j.rvsc.2010.05.003

Shen SY, Chang WC, Yi HH, Tsai SS, Liu HJ, Liao PC, Chuang KP, Vet. Immunol. Immunopathol. 167, 200-204, 2015. https://doi.org/10.1016/j.vetimm.2015.08.002

Simionatto S, da Veiga Lima-Rosa CA, Binneck E, Ravazzolo AP, Canal CW, Virus Genes 33, 5-10, 2006. https://doi. org/10.1007/s11262-005-0033-9

Smyth JA, Schat KA, In Gimeno IM (Ed.), Immuosuppressive Diseases of Poultry. Grupo Asis Biomedi Zazagoza, pp. 91-114, 2013.

Snoeck CJ, Komoyo GF, Mbee BP, Nakouné E, Le Faou A, Okwen MP, Muller CP, Virol. J. 9, 189, 2012. https://doi. org/10.1186/1743-422X-9-189

Sun GR, Zhang YP, Lv HC, Zhou LY, Cui HY, Gao YL, Qi XL, Wang YQ, Li K, Gao L, Pan Q, Viruses 9, 71, 2017. https://doi. org/10.3390/v9040071

Todd D, Avian Pathol. 29, 373-394, 2000. https://doi. org/10.1080/030794500750047126

Toro H, Van Santen VL, Hoerr FJ, Breedlove C, Avian Dis. 53, 94-102, 2009. https://doi.org/10.1637/8408-071408-Reg.1

Trinh DQ, Ogawa H, Bui VN, Baatartsogt T, Kizito MK, Yamaguchi S, Imai K, J. Gen. Virol. 96, 1086-1097, 2015. https://doi. org/10.1099/vir.0.000042

Ullah S, Riaz N, Umar S, Shah MA, World's Poult. Sci. J. 69, 125-134, 2013. https://doi.org/10.1017/S0043933913000111

Umar S, Ullah S, Yaqoob M, Shah MA, Ducatez M, World's Poult. Sci. J. 70, 759-766, 2014. https://doi.org/10.1017/ $\underline{S 0043933914000828}$

Wani MY, Dhama K, Latheef SK, Singh SD, Tiwari R, Vet. Med. Czech. 59, 2014.

Wani MY, Dhama K, Malik YS, Microb. Pathog. 96, 42-51, 2016. https://doi.org/10.1016/j.micpath.2016.05.003

Witter RL, Curr. Top. Microbiol. Immunol. 255, 57-90, 2001. https://doi.org/10.1007/978-3-642-56863-3 3

Yamaguchi S, Imada T, Kaji N, Mase M, Tsukamoto K, Tanimura N, Yuasa N, J. Gen. Virol. 82, 1233-1238, 2001. https:// doi.org/10.1099/0022-1317-82-5-1233

Zanella A, Dall'Ara P, Lavazza A, Marchi R, Morena MA, Rampin T, In Schat KA, Morgan RM, Parcells MS, Spencer JL (Eds.), Current Progress on Marek's Disease Research, pp. 11-19, 2001.

Zhang W, Li L, Deng X, Kapusinszky B, Delwart E, Virology 468, 303-310, 2014. https://doi.org/10.1016/j. virol.2014.08.025

Zhang X, Wu B, Liu Y, Chen W, Dai Z, Bi Y, Xie Q, Vaccine 33, 19161922, 2015. https://doi.org/10.1016/j.vaccine.2015.02.066

Zhang X, Liu Y, Wu B, Sun B, Chen F, Ji J, Ma J, Xie Q, Sci. Rep. 3, 3519, 2013. https://doi.org/10.1038/srep03519 